\title{
Youth Participation in Community Development (CD) Programmes in Cross River State: Implications for Sustainable Youth Development in Nigeria.
}

\author{
Udensi, Lawrence O. ${ }^{1}$, Daasi, Gibson L.K. ${ }^{2}$, Emah, Domale Sira ${ }^{2}$, \\ Zukbee, Sira A. ${ }^{2}$ \\ ${ }^{1}$ (Department of Sociology/Anthropology, University of Uyo, Uyo, Nigeria). \\ ${ }^{2}$ (Department of Banking and Finance, Rivers State polytechnics, Bori).
}

\begin{abstract}
Community Development anywhere in the world is facilitated by the extent to which the local people can mobilize their resources to address local needs. The role of the youths to fast-track Community Development Programmes has been recognized, particularly, in local communities where they have played pivotal role in education, health, environmental sanitation, mass mobilization, religious activities etc. This study poses that through active participation and encouragement; youths can be effective instrument for $C D$ programmes and may take ownership as well. With field-based data from Cross River State, South-South Nigeria, the study examines the extent and strategies to which the youth can be meaningfully engaged in $C D$ programmes and presents an evaluation of the challenges facing them in that direction. Recommendations for Sustainable Development via youth participation are made at the end of the study.
\end{abstract}

Keywords: Youths, Participation, Community Development, Programmes, Mobilization.

\section{Introduction}

According to reports from [1][2], about 50 percent of the developing world population are youths estimated at about 1.2 billion of age between 15 and 24 years. Of this number, about one billion live in developing countries alone. The above statistics indicate that youths constitute a serious development opportunity as well as a challenge particularly in developing countries. The imperative of youth participation in community development programmes considering their numerical strength is an unlimited window in which a larger and younger workforce who can drive economic development faster and play a significant role in national security, leadership and social development of their communities can be enhanced. Experts argue that, it will be impossible to reach the Millennium Development Goal targets, particularly on extreme poverty and hunger (MDG 1), child mortality (MDG 4), maternal health (MDG 5) and environmental sustainability (MDG 7) if the youths are not properly incorporated into the MDGs programmes.

The development of community is a dynamic process involving all segments of the locality, including the often-overlooked youth population. Youth represent a vast and often untapped resource for immediate and long-term community development efforts. They also provide an invaluable resource for program planning and effective evaluation. As youth are brought into and connected with community development programmes that they have often times been ignored or excluded from, they can participate in actively and contribute in decisionmaking at multiple levels. As youth are engaged in more sustained positive relationships with adults, other youth, and community development experts, apart from realizing that they are valued citizens of their communities, such collaborations and participation may lead to skill enhancement, empowerments and confidence-building traits, which will help prepare them for active CD services in future.

[3] has argued that youth must be fully engaged and involved in change efforts at the community level if they are to learn to function as effective members of society. Youth participation refers to their active involvement and real influence in the decisions that affect their lives. In this approach, participation quality is measured not only by its scope, such as the number of young people who attend a number of activities or are involved in a programme, but also by the quality of their contributions. Participation is effective when people (youth) have some positive effect on the CD process, influence a particular decision, or produce a favorable outcome [4].

An understanding of the level and extent to which youths in Cross River State has participated in community development programmes is a strong indicator to access the success of such programmes. Therefore, [5] calls for the creation of an institutional framework where all groups (especially the targeted ones) can take part with each other as equal partners and can set the frame within which planning can set the frame within which planning can happen. This postulates, therefore, that the people can only safeguard against this manipulation if they are organized. This necessitated redefinition of youth's participation in CD programmes. 


\section{OBJECTIVES OF THE STUDY}

The general objective of this study is to examine the extent and strategies to which the youth can be meaningfully engaged in CD programmes and also presents an evaluation of the challenges facing them in that direction. Specifically, this study is set to;

i. Examine the areas of youths participation in CD programmes in the study area

ii. Determine the level of youth participation in CD programmes in the study area

iii. Find out those factors that impede effective youth's participation in CD programmes in the study area.

\subsection{Youth Participation:}

\section{Conceptual And Theoretical Framework}

The merging of community development and youth development has been at the core of current research literatures [6] [7][8][9][10][11][12]. Community development literature emphasizes the importance of citizen participation as a means of strengthening communities [13] [14]. Advocates and practitioners of rural community development also believe that citizens should be meaningfully involved in community decisionmaking [15]. The above imply that, for development to occur there is need for a greater participation of local people in development process which will change the nature and direction of development intervention as well as result in a type of development which will have local people's support and recognition [16].

Youth participation according to [17] refers to the involvement of youth in responsible, challenging action that meets genuine needs, with opportunities for planning and/or decision-making affecting others in an activity whose impact or consequence is extended to others - i.e., outside or beyond the youth participants themselves. [18] notes that, "it is only through participation that youth develop skills, build competencies, form aspirations, gain confidence and attain valuable resources." This shows that youth participation therefore is a product and strategy of sustainable human development.

Youth comprise nearly 30 per cent of the world's population, these large numbers of young people are an opportunity; an investment to their communities. Youth participation in community development programmes therefore:

- Strengthens young people's abilities to meet their own subsistence needs;

- Prevents and reduces vulnerabilities to economic, political and socially unstable environments;

- Promotes ownership and sustainability of change interventions;

- Helps gain entry into target communities and build up trust and social capital.

\subsection{Community Development:}

Community development according to 19] is a social process by which human beings can become more competent to live with and gain some control over local conditions and the changing world. Bringing the foregoing to bear, there is need to give the main actors due opportunity to gain control over local conditions and to harness resources through effective leadership at the community levels. In the words of [20], community development has a longer history. And it's as old as human existence, because it seeks to improve man's standard of life. Community members who have the capacity to do something to enhance their quality of life are portrayed as having the ability to think, to decide, to plan and to take action in determining their lives. Therefore, in any community development programme both economic and individual growth must be given equal attention to ensure that the process of community development achieves its due balance (continuity and sustainability through adequate participation of all the key players in the community).

Community development in the words of [21] helps local community residents to identify unmet needs. It seeks to build capacity by improving skills and knowledge for individual and community as a whole. Central to the idea of community development is that it allows community residents to come together to plan, generate solutions and take action towards developing the social, economic, environmental and cultural aspects of community [22]. The whole process of community development according to [23] emphasizes the importance of participation as a means of strengthening local communities.

Finally, community development occurs when people strengthen the bounds within their neighborhoods, build social networks, and form their own organizations to provide a long-term capacity for problem solving [24]. The foregoing shows that every community development programmes should be aimed at changing an undesirable situation. Given that the youth population is on the high side in Nigeria communities, programmes directed at them become imperative and with their full, active and frequent participation, capacity for a long term problem solving can be developed.

\section{Imperatives Of Youth Participation In Community Development Programmes}

Various scholars have clearly points out the efficacy of youth participation in community development programmes. For instance, [25] and [26] succinctly observed that " participation helps youth in planning and 
acting together for the satisfaction of their felt needs through organized efforts to acquire skills and the concepts required for their effective participation in the problem solving process".

Young people constitute clear assets to community development programmes when they are positively empowered to be active citizens. Supporting and including young people in development processes is critical for several reasons: firstly, youth have experience, knowledge, and ideas that are unique to their situation, enabling them to offer key insights and perspectives on development that adults cannot; secondly, in many communities, youth make up the majority of the population; as a result, youth voices can be crucial expressions of overall community needs; and lastly, regardless of their current status, young people are the future custodians of their environments and leaders of their peers. A failure to promote youth development - and roles for youth in community development programmes - will negatively affect countries across the world, whereas engaging youths in community development programmes, such as taking active participation in the project planning and implementation encourages them to learn peaceful means of impacting their communities and the world.

Youths according to [27] have been noted for active involvement in community affairs, greater social propensity, faster reaction, time, innovative and prowess, it becomes necessary to exploit their active features for progressive change in the community through active and meaningful participation in programmes directed towards their development. Youths therefore needs proper harnessing so that they can maintain reliable status quo in their locality. It is easier for them to speak with one voice when they are brought together; that is why youth's participation in the various community development programmes will yield progress [28].

\section{Methodology}

This study was conducted in Cross River State, South - South Nigeria. Data for this study were generated from two different field works. Firstly, from Focus Group Discussion (FGDs) carried out in various locations in 3 local government areas (Calabar, Ikom and Ogoja) representing the 3 senatorial districts of Cross River State. Each FGDs consist of 10 youths purposively selected from the 3 LGAs selected for this study. Secondly, data from field work in 2011 by the authors. The study employed survey design using descriptive statistics to analyze quantitative data.

\subsection{Areas of Youths Participation in CD Programmes}

\section{Results And Discussion}

Table 1 shows the areas of participation of youth in CD programmes in the study area.

Table 1: Result of FGDs Showing Areas of Youth Participation in CD Programmes

\begin{tabular}{lccc}
\hline Programmes & FGD 1 & FGD & FGD 3 \\
Skill Acquisition & + & + & + \\
Education & + & - & + \\
Agriculture & + & + & + \\
Sports & + & + & + \\
Religion & - & + & + \\
Water project & - & + & + \\
$\quad$ Market & + & & \\
$\quad$ Town hall & - & & \\
Source: Field Work, 2012. & & & \\
+ : High level of participation & & & \\
- : Low level of participation. & &
\end{tabular}

Findings revealed a strong level of youth participation in programmes that they derive direct benefit. For instance, respondents show a high level of emphasis on programmes such as skill acquisition, agriculture and sport.

\subsection{Extent of Youth Participation in Community Development Programmes}

The extent of youth participation in $\mathrm{CD}$ programmes was obtained through careful computation, as is shown in Table 2. The various aspects of participation identified include: decision making, community mobilization, financial contribution, project legitimization, planning the project, monitoring/evaluating the project, raising funds for the project, and organizing skilled and unskilled labour for the project. 
TABLE 2: Distribution of Respondents According to their Extent of Participation in CD Programmes $(\mathrm{n}=150)$

\begin{tabular}{cccccccccc}
\hline $\begin{array}{c}\text { Points } \\
\text { Scale }\end{array}$ & $\begin{array}{c}\text { 1 Responses } \\
\text { Effective }\end{array}$ & $\begin{array}{c}2 \\
\text { Non Effective }\end{array}$ & Percentage & MWV & GAM & D & Rank & Remarks \\
Question & & & & & & & & & \\
1 & 117 & 33 & 78 & 22 & 25.4 & 23.1 & +2.3 & $2^{\text {nd }}$ & High \\
2 & 109 & 49 & 72.7 & 27.3 & 23.9 & 23.1 & +0.8 & $4^{\text {th }}$ & High \\
3 & 100 & 50 & 66.7 & 33.3 & 25 & 23.1 & +1.9 & $1^{\text {st }}$ & High \\
4 & 141 & 9 & 94 & 6 & 19.9 & 23.1 & -3.2 & $6^{\text {th }}$ & Low \\
5 & 140 & 10 & 93.3 & 6.7 & 20 & 23.1 & -3.1 & $5^{\text {th }}$ & Low \\
6 & 113 & 47 & 75.3 & 24.7 & 25.9 & 23.1 & +2.8 & $3^{\text {rd }}$ & High \\
$\sum$ & & & & & & & & & \\
\hline
\end{tabular}

Source: Field Survey, 2011

MWV=Mean Weight Value

GAM=Group Arithmetic Mean

$\mathrm{D}=$ Difference

High if MWV is greater than GAM and the difference is positive, but low if MWV is less than GAM and the difference is negative.

Results in Table 2 shows that the level or extent of participation by youths in community development project in the study area was significantly high in community mobilization which ranked first, followed closely by organising skilled and unskilled labour for the project. Financial contribution towards the project was ranked third; monitoring and evaluating the project was ranked fourth. However, the result show low level of participation by youth in decision making as well as accepting and legitimizing the project was ranked fifth and ranked sixth respectively.

From the foregoing analysis, it can be deduced that there is an average level of participation (62.55\%) by youths in various community development projects carried out in the study area, and this has lead to the success of various project studied.

\subsection{Challenges to Youth Participations in Community Development Programmes}

Researchers have identified various factors that are challenges to youth participation in community development programmes. Findings from a study on youths attitude to rural development projects by[29] revealed that improper and inadequate awareness, low level of exposure, Non-challant attitude, insufficient training, lack of encouragement by chiefs and elders of the community, intermittent change of government, and selfishness on the part of the youth leaders were the factors that affected youth participation in development programmes. Adequate awareness programmes should be put in place to encourage youths to participate more in rural development projects. Also, training in the form of participatory seminars and workshops would help the youths to be more proactive.

As a corollary of the foregoing, findings from the FGDs conducted as shown in Table 3 further revealed other challenges to youth's participation in CD programmes in the study area. Some of the challenges that respondents greatly emphasized in all the FGDs as challenges to their participation in CD programmes includes: inadequate awareness, non inclusion of youths in the planning stage, government policies, corruption etc.

Table 3: Result of FGDs Showing Factors that Impede Youth Participation in CD Programmes

\begin{tabular}{lccc}
\hline \multicolumn{1}{c}{ Challenges } & FGD 1 & FGD 2 & FGD 3 \\
Inadequate awareness & + & + & + \\
Poor programme planning & - & + & - \\
Tradition and culture & + & + & + \\
Non inclusion of youths in the planning stage & + & + & + \\
Lack of fund & + & + & + \\
Anticipated benefit & + & + \\
Government policies & & \\
Corruption & & \\
Source: Field Work, 2012. & & \\
$+\quad:$ Highly emphasized as a challenged & &
\end{tabular}


Monopolizing the planning process and decision making structure at the local level by initiators and facilitators of community development programmes will alienate citizens. According to [30], if the planning strategy being adopted is simply the type in which planners plan for the people and not the people, this strategy will not only negates democratic processes, but it also makes the citizens hostile to government projects designed to serve them and enhance their living conditions. In support of the foregoing, [31][32] noted that one of the major factors militating against successful rural community development is that government planners and administrators have often pushed development with little or no appreciation of the members of the community.

One significant challenge to effective youth participation in community development programmes is what [33] describes as "not being sure of the benefits of their contributions" and this can limit the active involvement of youth. To affirm the foregoing, [34] asserts that, research have shown that participation in community programmes in Nigeria is affected by the citizens' perception of the share of the anticipated benefit which will accrue to them as individuals. Moreover, the extent to which community member will take the initiative and also fully participate in community development programmes, depends on their perception of their roles vis-à-vis the role of the government with respect to that particular social issue or problem.

Result of a study by [35] on Youth Participation in Community Development: Evidence from Yakurr Local Government Area, Cross River State indicated that:

Inadequate funding $(37.8 \%)$ hamper the execution of major developmental projects in the community. Most youth organizations depend on voluntary donations by members or other organizations for the execution of their projects. Poor leadership within the organization $(16.7 \%)$ is another major factor affecting youth participation in rural development in the study area. Respondents complained that some leaders could not give proper account of their stewardship in the organizations. Also, $14.4 \%$ of the respondents indicated that lack of interest by community members was a limiting factor towards participating in rural development in the area.

Another constraint to youth participation in development is the issue of lack of training, which stood at $11 \%$.

In addition to Effiongs' findings above, [36] observed that, the problem of participation is perceived in terms of "whether the people know what they want". Some local people ask for the impossible things, or merely repeat a long list of conventional development which has been told should want and sometimes they say they do not want anything to change. [37] puts it succinctly by asserting that the real problem is that the average citizen has a very little idea of the range of options open to him, or of the implications of these various options. It is not surprising, according to him, that rural people would often ask for the impossible or for what others have told them they should want. It is also natural that because of a very understandable fear of the unknown, he may say he wants things to stay as they are, particularly if there is any form of risk attached to the proposes development.

Finally, other challenges, such as parental involvement, can facilitate influences on youth participation or involvement in community development programmes. [38] Observed that youth whose parents are actively involved in the community activities are more likely to become active themselves. However, youth whose parents do not participate in civic activities according to) [39] may still become active and participate in their communities programmes; however, a supportive and reinforcing parental relationship may have a greater contribution to civic engagement than parental modeling. Perhaps as a result of an increased awareness of the advantages for youth, parents play an important role in linking their children to the world around them [40].

\section{Conclusion}

Young people are increasingly recognized as significant agents in the realization of both community and national development programmes. Throughout the world, hundreds of thousands of young people are spearheading positive social change - leading community initiatives, operating small businesses, and re-shaping political processes. With more than one in five of the world's population between the ages of 12 and 24, and with 1.3 billion of these young people living in developing countries, it is imperative that youth develop the skills they need to contribute to their families, their countries, and the global community. Youth participation therefore is a mechanism that enables youth to gain these skills while simultaneously changing their communities. The involvement of today's youth in community development programmes especially in its decision-making and implementation is critical to sustainable youth development in Cross River State and Nigeria in general.

\section{Recommendations}

It is imperative that youths participate actively in all relevant levels of decision-making processes because it affects their lives today and has implications for their futures. In addition to their intellectual contribution and their ability to mobilize support, they bring unique perspectives that need to be taken into account. 
There is need to engage youth in recreational activities that enhance social cohesion. This includes development of community based infrastructure, promoting arts, culture, sport and overall entertainment of youth. This will promote social and national integration of youth.

There is need to channel and redirect young people's energies towards positive direction by creating an environment that will enable them to reclaim their space for creative cultural expression. This will inculcate in youth a sense of belonging, self-worth and self-identity. This can be achieved through active mobilization and engagement of youth on issues affecting their lives.

The cultivation of nationhood, patriotism as well as respect, understanding and tolerance of fellow human beings irrespective of their culture and religion will help promote well balanced youth who actively participate in the development of the country.

Government in collaboration with all stake holders should ensure that young people are targeted in social development programmes such as sustainable livelihoods, social protection, social assistance and welfare services;

Government should progressively facilitate inclusion of youth representatives in national structures that seeks to develop them and their communities

Engaging youth in meaningful activities that benefit their communities while developing their abilities and skills will help build a cohesive society and inculcating a strong sense of responsibility and further provide life-changing opportunities for the youth

Adequate sensitization is necessary for proper awareness of community development programmes, especially programmes that are targeted at the youth. This will increase youth participation in development programmes. Finally;

Government should strengthen its relations with civil society organizations involved in youth development and ensure that they are profiled and supported so that they can become accessible to all young people

\section{Reference}

[1] United Nations, 2005 Figures of World Population Prospects: 2008 revision (Geneva: UN Population Division, 2008).

[2] World Bank, World population report (Washington: D.C.: World Bank, 2010).

[3] J. Nitzberg, The meshing of youth development and community building, putting youth at the center of community building, new directions for youth development, No. 106, summer 2005.

[4] B. Checkoway, Involving young people in neighborhood development. Children and Youth Services Review, 20, 1998, 765-795.

[5] A. E. Luloff, and L. Swanson, Community agency and disaffection: enhancing collective resources, in L. Beaulieu, and D. Mulke, (Ed.) Investing in people: the human capital needs of rural America, (Boulder, CO: Westview Press, 1995).

[6] J. Nitzberg, The meshing of youth development and community building, putting youth at the center of community building, new directions for youth development, No. 106, summer 2005.

[7] A. C.Kubisch, Comprehensive community building initiatives--ten years later: what we have learned about the principles guiding the work, putting youth at the center of community building, new directions for youth development, No.106, summer 2005 .

[8] E. S. Cahn, \& C. Gray, Using the co-production principle: no more throwaway kids. Putting youth at the center of community building, new directions for youth development, 106: summer 2005.

[9] A. Lynn, Youth using research: Learning through social practice, community building, and social change. putting youth at the center of community building, new directions for youth development, No. 106, summer 2005.

[10] M.A. Brennan, R. Barnett, and M. Lesmeister, Enhancing leadership, local capacity, and youth involvement in the community development process: findings from a Survey of Florida youth, Journal of the Community Development Society, (forthcoming), (2006).

[11] M.A. Brennan, R. Barnett, and M. Lesmeister, An exploration of factors shaping youth involvement in community development: Findings from a survey of Florida youth, Journal of the Community Development Society, 38(4), 2008, 13-27.

[12] M.C. Okwusi, Youths attitude to rural development projects in Ogba communities of Rivers state, Nigeria, Global Approaches to Extension Practice, 4 (1), 2008, 11-19.

[13] K.P. Wilkinson, In search of the community in the changing country side, Rural Sociology, 51 (1), 1986, 1-17.

[14] C.B. Flora, J.L. Flora, and S. Fey, Rural communities: legacy and change, $2^{\text {nd }}$ ed. (Boulder, CO: Westview, 2004).

[15] B. A. Coe, Open focus: A model of community development. Journal of the Community Development Society, 21 (2), 1990, 20-35

[16] CASSAD. Non -government organizations in Nigerian communities: A critical evaluation of their characters, achievements and potentials for social and economic development: summary of the study report, 1992, 25-26.

[17] G.P. Cornwall, Youth participation in local (community) level development: A development strategy, paper presented at the 11th Annual Salises Conference St.Augustine Trinidad, March 24-26, 2010.

[18] R.R. Rajani, Promoting strategic adolescent participation: A discussion paper for UNICEF, 1999

[19] A.R Ajayi, Community self-help project implementation procedures: A case study of Ekiti south-west local government area of Ondo state. Agrosearch, 1 (1), 1995, 47-55.

[20] B. Kleiner, K. Rave, G. Silverstein, R. Bell, and J. Well, Evaluation of the Appalachian regional commission's community capacity building projects (Washington D.C.: Appalachian Regional Commission, 2004).

[21] A. Gilchrist, The well connected community: A networking approach to community development. (UK: The policy press, 2004).

[22] H. Hackett, Community capacity building, paper presented at the conference of social assistance professionals in the provincial and municipal sector, 2004, available online at: http://www.ranaprocess.com/articles/community, retrieved $29^{\text {th }}$ may 2009.

[23] F. A. Kuponiyi, Community power structure: The role of local leaders in community development decision making in Ajaawa, Oyo State, Nigeria, Anthropologist, (4), 2008, 239-243.

[24] J. Rubin, and S. Rubin, Community organizing and development, $3^{\text {rd }}$ ed. (Boston: Allyn and Bacon, 2001).

[25] G. Jibowo, Essentials of rural sociology, (Abeokuta: Gbemi Sodipo press, 1992). 
[26] L.A. Akinbile, O.R. Ashimolowo, and M.A. Oladoja, Rural youth participation in infrastructural development of Ibarapa East local government area of Oyo State. Nigeria Journal Rural Sociology, 6(1 \&2), 2006, 40-48.

[27] O. M. Adesope, Agricultural youth organizations: introductory concepts (Port Harcourt: University of Port Harcourt Press, 2007).

[28] A.O. Angba, O.M. Adesope, and C.L. Aboh, Effect of socioeconomic characteristics of rural youths on their attitude towards participation in community development projects, International NGO Journal, 4 (8), 2009, 348-351.

[29] M.C. Okwusi, Youths attitude to rural development projects in Ogba communities of Rivers State, Nigeria, Global Approaches to Extension Practice, 4(1), 2008,11-19.

[30] E.A. Udoh, Participation and sustainable community development: The case of Eastern Obolo community development foundation, masters thesis, department of sociology and anthropology, University of Uyo, Nigeria, 2012).

[31] E.M. Abasiekong, Mass participation: an essentials element for rural development programme in developing countries (Calabar: Scholar press, 1982).

[32] E.M. Abasiekong, Mass participation in rural development programmes: problems and prospects, seminar paper, University of Calabar, Calabar, Nigeria, 1990.

[33] G. D. Israel, D. L. Coleman, and T. W. Ilvento, Student involvement in community needs assessment, Journal of Community Development Society, 24(2), 1993, 249-271.

[34] E. E. Ekong, Rural sociology, $3^{\text {rd }}$ ed. (Uyo: Dove, 2010).

[35] J.B. Effiong, Youth participation in community development: evidence from Yakurr local government area, Cross River State, International Journal of Social Science Tomorrow, 1(6), 2012,

[36] E.A. Udoh, Participation and sustainable community development: The case of Eastern Obolo community development foundation, masters thesis, department of sociology and anthropology, University of Uyo, Nigeria, 2012).

[37] E.M. Abasiekong, and I.V.O. Modo, High points in development (Uyo: Dorands publishers, 1994).

[38] C. G. Chan, and G. H. Elder, Family influences on civic involvement, unpublished manuscript cited in Fletcher et al, 2000, 1999)

[39] C. Flanagan, and B. Van Horn, Youth civic engagement: Membership and mattering in local communities (California: Focus Davis 4-H center for youth development, University of California, 2001).

[40] R. D., Parke, and G. W. Ladd, Family-peer relationships: Modes of linkage (Hillsdale, NJ: Lawrence Erlbaum Associates, Inc, 1992). 